ÇOMÜ Uluslararası Sosyal Bilimler Dergisi 3 (2), 211-231 , 2018

COMU International Journal of Social Sciences 3 (2), 211-231 , 2018

\title{
Otomotiv Endüstrisindeki Dönüşüm ve Türkiye *
}

Ayfer USTABAȘ ${ }^{* *} \odot$

Osman SIMAV ${ }^{* * *}$

Öz

Araştırmanın amacı, Türkiyede elektrikli araçların yaygınlaşmasının istihdam, çevre ve diş ticaret dengesi üzerindeki olası etkilerin bu endüstride yönetici olarak çalışanların görüşlerinden yola çıkarak irdelenmesidir. Bu bağlamda, kolayda örnekleme yoluyla ve mülakata izin veren beş katılımcıdan oluşan örneklem ile açık uçlu sorular aracıllğıyla derinlemesine mülakatlar yapılmıștır. Katılımcılardan üçü, Türkiyede elektrikli araçların satış ve satış sonrası hizmetlerini veren otomotiv firmaların üst düzey yöneticileridir. Dördüncü katılımc1, otomotiv konusunda ulusal televizyon kanallarından birinde program hazırlayan bir gazetecidir. Beşinci katılımcı ise Türkiye’de elektrikli araçlar konusunda çalışan bir sivil toplum kuruluşunun yöneticisidir. Bulgulara göre, Türkiyede elektrikli araçların yaygınlaşmasında kamu güveninin sağlanması, tüketicilere ve üretici firmalara finansal teşviklerin ve vergi desteklerinin sunulması en önemli koşullar olarak ön plana çıkmaktadır. Katılımcıların ortak görüşü, elektrikli araçların yaygınlaşmasının Türkiye ekonomisinde çevre ve dış ticaret dengesi açılarından orta vadede olumlu etkilere sahip olacağıdır. İstihdam konusunda ise net bir görüş birliği ortaya çımamıştır.

Anahtar Kelimeler: Otomotiv Endüstrisi, Elektrikli Otomobiller, İstihdam, Çevre, Dış Ticaret Dengesi

\footnotetext{
* Bu çalışma, 5 Ekim 2017 tarihinde Uluslararası Avrasya Ekonomileri Konferansı’nda (AVEKON 2017-Bişkek) sunulan "Otomotiv Endüstrisindeki Muhtemel Dönüşümün Ekonomik Boyutu: Türkiye Örneği” başlıklı bildirinin sunum sonrası genişletilmiş ve revize edilmiş biçimidir.

** Dr. Öğr. Üyesi, Beykent Üniversitesi, ayferustabas@beykent.edu.tr

(C) Sorumlu Yazar / Corresponding Author

*** Dr. Öğr. Üyesi, Beykent Üniversitesi, osmansimav@beykent.edu.tr
} 


\title{
Transformation in Automotive Industry and Turkey
}

\begin{abstract}
The aim of this study is to investigate the potential effects of widespread adoption of electric vehicles on the employment, environment and foreign trade balance in Turkey based on the opinions of the managers working in this industry. Thus, reported here are in-depth interviews conducted through open-ended inquiries with a sampling comprising of five participants. Three participants are Managers of automotive firms providing sales and after-sales services for electric vehicles in Turkey. Fourth participant is a journalist who prepares television programs about the automotive industry for a national channel. Finally, the fifth participant is the manager of a nongovernmental organization working about electrical cars in Turkey. According to findings, establishment of public consciousness and trust, provision of financial incentives and export incentives and tax supports to consumers and producers come to the fore as the most important conditions. Participants' common view is that the increase in the market share of electrical cars might have positive effects on Turkey's economy through environment and foreign trade balance in the medium term. As regards employment, a clear consensus has not emerged.
\end{abstract}

Keywords: Automotive Industry, Electric Cars, Employment, Environment, Foreign Trade Balance

\section{GíRIş}

Otomotiv endüstrisi, tüm dünyada gıda, tekstil ve makine sanayileri ile birlikte önemli bir ana endüstri kolu olarak yüz yılı aşkın bir süredir tüm insanlığın ilgi odağında olmuştur. İnsanların özgürce bir yerden bir yere gitme isteklerine cevap veren binek otomobillerin yanı sıra ürünlerin istenilen yerlere taşınmasını sağlayan tırlar, kamyonlar ve kamyonetler ve insanların toplu olarak taşınmasını sağlayan otobüs, minibüs gibi araçlar da otomotiv endüstrisinin önemli ürünleridir.

1880'lerde Avrupa'da ilk ürünleri görülen otomotiv endüstrisi, 1900'ün ilk yıllarında özellikle Henry Ford'un seri üretim yoluyla maliyetleri düşürmesiyle Amerika Birleşik Devletleri’nde sanayinin itici gücü olmuştur. Endüstrinin ilk dönüm noktası olarak kabul edilen bu gelişme sonrasında ikinci dönüm noktası, 1960'lardan sonra Toyota firmasının öncülüğünde Yalın Üretime (Lean Production) geçiş olarak kabul edilmektedir. Müşteri talebine göre stoksuz, çok daha ucuza kaliteli otomobiller imal edilmesini sağlayan bu sistem sayesinde kaliteli ve uygun fiyatlı ürünler etkin bir şekilde üretilebilmektedir (Freeman ve Soete, 2004: 180). 
2000'li yıllara gelindiğinde, fosil yakıt kullanan içten yanmalı motorlu araçlar yerine çevre dostu araçların üretilmesi ve satışı giderek artmaya başlamıştır. Bunun en önemli nedenleri arasında, tükenmekte olan petrol ve diğer fosil kaynaklara bağımlılığın azaltılmasının yanı sıra insan kaynaklı hava kirliliğinin ve zararlı karbon emisyonlarının ortadan kaldırılması sıralanmaktadır. Sonuç olarak, çevre dostu araçların otomotiv endüstrisindeki üçüncü büyük dönüm noktasını ya da muhtemel dönüşümü gerçekleştireceği iddia edilmektedir (Lepetun, 2011: 4-11).

Çevre dostu araçlar arasında üç temel teknoloji yaygın olarak geliştirilmiştir. Bunlardan ilki, konvansiyonel içten yanmalı motor ile araç tarafından üretilen enerji ile şarj olan bataryanın birlikte kullanıldığı hibrit araçlar, ikincisi kablo ile şarj edilebilen hibrit veya tümü elektrikli araçlar, üçüncüsü hidrojen yakıt hücreleri ile beslenen elektrikli araçlar şeklinde özetlenebilir (Dicken, 2009: 486). Ayırt edici olabilmesi açısından, bu çalışmada "hibrit araç" ilk gruptaki araçları, "elektrikli araç" ise ikinci ve üçüncü araç grubunu ifade etmektedir (Global EV Outlook, 2018: 9).

2017 yılında tüm dünyada elektrikli araç satış1, 2016 yılına göre yüzde 54 artış göstererek bir milyonun üzerinde gerçekleşmiştir. Norveç, yüzde 39 pazar payıyla dünya çapında bu araçların en başarılı şekilde yaygınlaştığ ülke olmuştur. Norveç’i yüzde 11,7 ve yüzde 6,3 pazar payları ile sırasıyla İzlanda ve İsveç izlemektedir. Çin, tüm dünyada satılan elektrikli araçların yüzde 40’ından fazlasına sahip olan ülke olarak dünyanın en önemli elektrikli araç pazarı olarak ortaya çıkmaktadır. Çin’i Amerika Birleşik Devletleri izlemektedir. 2010-2017 döneminde satışı yapılan küresel elektrikli araç sayısı ise 3 milyon aracı geçmiştir (Global EV Outlook, 2018: 9).

Türkiye'de ise 2017 yılında satılan 722.759 araçtan sadece 76 adedi yani yüz bin araçtan yaklaşı olarak on bir adedi elektrikli araç iken 4.507 adedi yani yüz bin araçtan 623 adedi hibrit araçtır (Tablo 1).

Toplam araç parkı kapsamında ise, 2018 Mart ayı sonu itibarıyla trafiğe kayıtlı 11 milyon 493 bin 249 adet otomobilin yüzde 39'u likit petrol gazlı, yüzde 34,1'i motorin yakıtl, yüzde 26,5’i benzin yakıtlıdır (TÜİK, Mayıs 2018). Toplam araç parkının sadece 502 adedi elektrikli ve 7,580 adedi hibrit araçtır (Tablo 1). Bu oran, diğer ülkelerle kıyaslandığında çok düşük kalmaktadır.

5 Elektrikli araçlar kavramı ile şarj edilebilir hibrit, tümü elektrikli ve yakıt hücreli elektrikli araçlar yani bir önceki paragraftaki ikinci ve üçüncü gruptaki araçlar ifade edilmektedir. 
Tablo 1: Türkiye’de Trafikteki Motorlu Araçların Yakıt Türlerine Göre Dağılımı

\begin{tabular}{|c|c|c|c|c|c|c|c|c|c|c|c|c|}
\hline MOTORHACMI & MOTOR CINSI & 2011 & 2012 & 2013 & 2014 & 2015 & 2016 & 2017 & $\begin{array}{l}2018 \\
\text { Ocak- } \\
\text { Mart } \\
\end{array}$ & TOPLAM & OTV $\%$ & KDV $\%$ \\
\hline$\leq 160000$ & B.D & 530,069 & 514,861 & 626,047 & 558,995 & 695,113 & 729,324 & 694,464 & 117,363 & $4,466,236$ & $45,50,60$ & \\
\hline $1601 \alpha-\leq 2000 \alpha c$ & $B D$ & 52,396 & 35,850 & 32,609 & 22,536 & 23,105 & 22,521 & 21,568 & 3.460 & 214,045 & 100,110 & \\
\hline$\geq 200100$ & B.D & 11,054 & 5,385 & 5,968 & 5,753 & 6,284 & 4,039 & 2,144 & 350 & 40,977 & 160 & \\
\hline$\leq 85 \mathrm{~kW}$ & ELEKTRIK & - & 184 & 31 & 22 & 38 & 23 & 55 & 36 & 363 & 3 & \\
\hline $86 \mathrm{~kW}-\leq 120 \mathrm{~kW}$ & EIEKTRIK & - & & - & - & - & - & - & - & - & 7 & \\
\hline$\geq 121 \mathrm{~kW}$ & ELFKTRIK & - & & - & 25 & 82 & 21 & 21 & 12 & 149 & 15 & \\
\hline$<=16000 c$ & HIBRIT & & & & & 963 & 886 & 464 & 147 & 2460 & 60 & \\
\hline $\begin{array}{l}1601 \alpha-c=1800 \mathrm{cc} \\
(<=5 \mathrm{KK} \mathrm{V})\end{array}$ & HIBRIT & & & & & - & - & - & - & - & 110 & 18 \\
\hline $\begin{array}{l}1601 \propto-c=1800 \alpha c \\
(>50 \mathrm{KW})\end{array}$ & HIBRIT & & & & & 3 & - & 3,704 & 885 & 4592 & 60 & \\
\hline $1801 \alpha-c=2000 \propto x$ & HIBRTT & & & & & - & 89 & 63 & 2 & 154 & 110 & \\
\hline $\begin{array}{l}2001 \propto-c=2500 c c \\
(<=100 \mathrm{KTW})\end{array}$ & HIBRTT & & & & & - & - & - & - & 0 & 160 & \\
\hline $\begin{array}{l}2001 \alpha-\epsilon=1500 \mathrm{c} \\
(>10 \mathrm{KW})\end{array}$ & HIBRIT & & & & & 2 & - & 266 & 52 & 320 & 110 & \\
\hline-250000 & HIBRIT & & & & & 6 & 35 & 10 & 3 & 54 & 160 & \\
\hline TOPLAM & & 519 & 566280 & 664655 & 7,331 & 725,996 & 56.938 & 759 & 122,310 & 40 & & \\
\hline
\end{tabular}

Kaynak: ODD Türkiye pazarı raporlarından derlenmiştir (Mayıs 2018).

Bu çalışmanın amacı, Türkiye'de elektrikli araçların pazar payındaki artışların otomotiv endüstrisi istihdamı, çevre ve dış ticaret dengesi açılarından ekonomide yaratacağı olası etkileri bu endüstride yönetici olarak çalışanların görüşlerinden yola çıkarak araştırmaktır. Araştırmanın birinci bölümünde, Türkiye’de ve dünyada elektrikli araçların gelişimi incelenmektedir. İkinci bölümde, elektrikli araçların yaygınlaşmasının ekonomide oluşturabileceği etkiler istihdam, çevre ve dış ticaret dengesi başlıkları altında yer almaktadır. Üçüncü bölümde, konu ile ilgili yazın araştırması, dördüncü bölümde araştırmanın yöntemi ve son bölümde araştırmanın bulguları açıklanmaktadır. Araştırma, sonuç ve öneriler bölümü ile sona ermektedir.

\section{TÜRKIYY'DE VE DÜNYADA ELEKTRİKLI ARAÇLARIN GELISŞIMİ}

1750'lerde İngiltere'de endüstri çağı ile kullanılmaya başlanan buhar enerjisi sayesinde ilk otomobil diyebileceğimiz ilk buharlı taşıt, 1769'da Cugnot tarafından Fransa'da imal edilmiştir. Saatte 3-4 km hızla gidebilen bu taşıttan sonra 1890'lara kadar Batı Avrupa ve Amerika Birleşik Devletleri’nde değişik tipte yüzlerce araç yapılmıştır (Bedir, 2002: 2). Elektrikli aracın icadında birçok mucidin adı geçmektedir. 1828'de, Macar Ányos Jedlik elektrik motoru ile hareket eden küçük bir model yapmıştır (Haktanır, 2012: 11).

İlk elektrikli araç modeli, 1835 yılında Hollanda'da Profesör Stratingh tarafindan oluşturulmuştur. Bundan sonra, bataryalı ilk elektrikli yol aracı 1834-1836 yılları arasında Amerika Birleşik Devletleri'nde Thomas Davenport tarafından geliştirilirken, 1839 yılında, Robert Davidson şarj edilemeyen bataryalı elektrikli lokomotifi geliştirmiştir (Ünlü vd, 2003: 16). 
1900-1912 yılları arasında elektrikli araçların altın dönemi yaşanırken 1920'lerin ortasından 1960 yıllara dek, içten yanmalı motorlu otomobiller, buharlı ve elektrikli otomobillerden çok daha fazla imal edilmeye ve satılmaya başlanmıştır. Elektrikli ve buharlı otomobillerin imalat adetleri çok azalmış, buhar makinası gemi ve demiryolunda yaygın olarak kullanılmaya başlanmıştır. 1960-1990 döneminde ise elektrikli otomobiller az sayıda da olsa tekrar görülmeye başlamıştır (Ünlü vd. 2003: 18).

Petrol fiyatlarındaki istikrarsızlık, hava kirliliğinin kötüleşmesi ve küresel iklim değişikliği ile ilgili oluşan çevre bilinci sonucunda, elektrikli araçlar 1990'lı yıllarda yeniden gündeme gelmiştir. Bu yeni ilgi, 2010'da elektrikli araçların seri üretiminin başlamasıyla daha da somut hale gelmiştir (Global EV Outlook, 2013: 8).

Çevre ile ilgili kaygıların yanı sıra, 2000'li yılların başında başlayan ve 2008 krizi sonrasında zirveye ulasan ekonomik durgunluk, otomobil üreticilerini durgunluğun nedenlerinden biri olarak görülen aşırı yakıt tüketen büyük hacimli otomobiller yerine küçük, çevre dostu araçlara yöneltmiştir. Elon Musk tarafından Kaliforniya’da kurulan Tesla Motors, 2004 yılında, ilk müşterilerine 2008'de teslim edilen elektrikli Tesla Roadster'i geliştirmeye başlamıştır. Otomotiv sanayinde önemli bir adım olan Tesla’nın bu girişiminden sonra Nissan, Leaf modelini 2010'da Amerikan pazarında satışa sunmuştur. Renault, elektrikli Fluence ve Zoe modellerini üretmiştir (Ustabaş, 2013: 45-46). Günümüzde bu modellerin yanı sıra, BMW İ3 ve İ8 (Hibrit) modellerini, Volkswagen, Daimler Benz, General Motors ve Ford gibi büyük otomotiv üreticileri de farklı elektrikli otomobil modellerini satışa sunmaktadırlar. 5 Temmuz 2017'de yapılan açıklamaya göre Volvo, 2019 yılından itibaren satışa sunacağı tüm araçların tümü elektrikli veya hibrit olacağını açıklamıştır (The Guardian, 2017).

Türkiye’de Tübitak Marmara Araştırma Merkezi'nin 2003 yılından itibaren hibrit ve elektrikli araçlar konularında gerçekleştirdiği projeler arasında; ELİT-1, FOHEV-1 ve Sultan araçları yer almaktadır. Bunların yanı sıra, çeşitli üniversiteler tarafından veya bağımsız projeler ya da sanayi-üniversite iş birliğinde elektrikli araçlar ve alt sistemlerinin geliştirme araştırmaları da devam etmektedir (Haktanır, 2012: 13).

Türkiye'de elektrikli otomobil üretimi ve satısı konusunda ilk faaliyete geçen firmalardan olan Renault, 2012 yılında elektrikli Fluence Z.E. aracını Bursa'daki fabrikasında üretmiştir ve satışa sunmuştur. Öte yandan, bu araç hedeflenen satış rakamlarına ulaşamadığından 2013 yılı sonunda üretimine son verilmiştir. Ülkemizde Haziran 2018 itibariyle satışı gerçekleşen tümü elektrikli araç modelleri; Renault Zoe, BMW İ3 ve Jaguar I-PACE ve şarj edilebilir hibrit araç modelleri ise BMW İ8, BMW 740e, BMW X5 xDrive 40e, BMW 330e, BMW 225xe, Mercedes Benz GLC350e, Porsche Panamera ve Volvo XC90 T8'dir (TEHAD, 2018: 1).

Elektrikli araçların 2000’li yıllarda tekrar gündeme gelmesindeki nedenlerden ilki, petrol fiyatlarındaki istikrarsızlık ve fosil yakıtların tükenmesi tehlikesi sonucunda bu yakıtlara duyulan bağımlılı̆̆ın azaltılması hedefidir. Her ne kadar bulunan yeni petrol yatakları 
ile daha uzun yıllar yeterli petrolün çıkarılabileceği tahmin edilse de sonuç olarak bu kaynaklar belli bir zaman içinde tükenecektir (Lepetun, 2011: 8-11).

Elektrikli araçların üretimine yönelmenin diğer önemli nedeni ise, ulaşım kaynaklı egzoz emisyonlarının neden olduğu hava kirliliği ve sera gazı emisyonunun azaltılmasıdır. Uluslararası Enerji Ajansı’nın 2017 raporuna göre, fosil yakıt kullanan içten yanmalı motorlu karayolu taşıtlarının hava kirliliğine etkileri bazı kirleticilerde toplam emisyonun yüzde 50'sini teşkil edecek derecede ciddi boyutlara ulaşmaktadır. Özellikle dizel motorlu araçların egzozundan atılan partikül maddelerin azaltılabilmesi için sıfır emisyonlu araçlara geçilmesi bu nedenle bir zorunluluk haline gelmiştir. Aralık 2015’ta açıklanan, Kasım 2016'da yürürlüğe giren Paris Anlaşmasına göre, ortalama küresel sıcaklık artışının sanayileşme öncesine göre 2 santigrat derecenin altında kalması ve mümkünse 1,5 santigrat derece ile sınırlanmasına yönelik çabaların devamı yönünde anlaşmaya varılmıştır (Global EV Outlook, 2017: 8).

Elektrikli araçların yakın ve orta vadedeki satışları ile ilgili çok sayıda tahmin yapılmaktadır. Uluslararası Enerji Ajansı (IEA), ülkelerin ve üretici firmaların öngörülerine dayanarak elektrikli araç sayısının 2020 yılında 13 milyon ve 2030 yılında yaklaşık olarak 130 milyon civarında olacağını tahmin etmektedir (IEA, 2018: 75).

British Petrolium, 2015 yılında 1,2 milyon olan elektrikli araç sayısının önemli bir artış göstererek 2035’te 100 milyon civarına yükseleceği (küresel filonun yüzde 6’sı) tahminini yapmıştır (BP, 2017). Exxon Mobil, 2040 yılı elektrikli araç tahminini 65 milyondan 100 milyona yükseltirken, Norveçli Statoil ASA, 2030'dan itibaren toplam satışların yüzde 30’unun elektrikli araç olacağı tahminini yapmıştır (Özpeynirci, 2017: 8). Otomotiv konusunda strateji danışmanlı̆̆ 1 yapan Frost ve Sullivan şirketi ise, üretici firmaların hedeflerinin gerçekleşmesi durumunda 2025’e gelindiğinde yaklaşık 25 milyon elektrikli aracın satılacağını yani dünya genelinde satılan araçların yüzde 20'sinin elektrikli olacağını öngörmektedir (ODD dergi, 2018: 22)

Elektrikli araçların orta vadede yaygınlaşmasıyla ilgili bu olumlu bakış açısına rağmen, elektrikli araçların pazar payının kısa vadede artışının önünde bazı engeller olduğu ileri sürülmektedir. Bu engeller, bu araçların menzillerinin içten yanmalı motorlu araçlara göre sınırlı olması, şarj sürelerinin uzunluğu ve yüksek batarya maliyetinden kaynaklanan ilk satın alma maliyetinin yüksek olması olarak sıralanmaktadır (OTEP, 2010: 13-14).

Günümüzde elektrikli araçlarda yaygın olarak kullanılan lityum iyon akülere alternatif olan diğer enerji kaynağı yakıt hücresidir. Hidrojenin havanın oksijeni ile birleştirilerek elektrik elde edilen yakıt hücrelerinden ortaya çıkan atık madde sudur (Ünlü vd. 2003: 13). Yakıt hücrelerinde kullanılan katalizör madde olan platinin pahalı olması ve hidrojenin depolama zorluğu yüzünden kısa sürede maliyetlerde önemli düşüşler beklenmemektedir. Bundan dolayı, sıfır emisyonlu araçlar için yakın dönemde enerji kaynağının lityum esaslı aküler olacağı öngörülmektedir. Bu alanda üç temel batarya teknoloji ailesi ön plana çıkmaktadır: konvansiyonel lityum iyon, intermetalik anot kullanan ileri lityum iyon ve 
bunun ötesine giden lityum sülfür içeren lityum metal ve lityum hava gibi teknolojiler (Global EV Outlook, 2017: 13).

Tesla ile Panasonic firmalarının ortaklaşa geliştirdikleri lityum iyon piller ile güç ve enerji yoğunluğu yüksek akülerin maliyetinin yüzde 30 kadar düşürülmesi ile de içten yanmalı motorlu araçlar ile rekabet edebilir hale gelmişlerdir. Süper şarj üniteleri bu tip akülerin daha doğrusu pillerin 10 dakika seviyelerine kadar indirilen dolum süreleri ile önümüzdeki yıllarda çok daha yaygın olarak kullanılacağı tahmin edilmektedir (Tesla, 2017).

Elektrikli otomobillerde otomobil fiyatının yaklaşık yüzde 30-40’ını oluşturan bataryanın ömrünün yedi ila sekiz yıl civarında olması bu araçların maliyetini artıran en önemli unsurdur. Teknolojinin gelişimi ile akümülatör ömürlerinin ve garanti sürelerinin on yılın üzerine çıkarılması ile batarya maliyetinin düşürülmesi beklenmektedir. Bataryanın pahalı olmasından dolayı halen elektrikli otomobiller, içten yanmalı motorlu otomobillere göre yaklaşık yüzde 40-50 civarında daha pahalıdır. Bu farkın azaltılması için bazı ülkeler vergi indirimleri veya vergi iadeleri ile destek sağlamaktadırlar. Özellikle, Amerika Birleşik Devletleri’nin Kaliforniya eyaletinde sağlanan vergi indirimleri ile her iki otomobilin fiyatları neredeyse eşit seviyelere gelebilmektedir. Kuzey Avrupa ülkelerinde olduğu gibi diğer bir önemli destek elektrikli otomobillerin toplu taşım için ayrılmış özel yolları kullanabilmelerinin sağlanmasıdır. İçten yanmalı motorlu otomobillerin şehir merkezlerine girişlerinin yasaklanması, buna mukabil elektrikli otomobillerin otoparkları ücretsiz olarak kullanarak şehir merkezlerinde rahatlıkla dolaşmalarının sağlanması bu tip araçlar için çok önemli bir teşvik olmaktadır. Tesla, BMW ve Renault gibi elektrikli otomobil üreticilerinin bir diğer teşvikleri ise elektrikli otomobillerin kendi servis veya şarj istasyonlarında şarj edilmelerinde şimdilik ücret almamalarıdır (İlgili firmalardan edinilen bilgiler).

Elektrikli araçların satın alma maliyetinin düşürülmesi için Türkiye’de bazı vergi destekleri sağlanmaktadır. Örneğin, ülkemizde Özel Tüketim Vergisi, 2018 Haziran ayı itibariyle, içten yanmalı motorlu araçlar için, motor silindir hacmine göre yüzde 50 ile yüzde 160 arasında değişirken elektrikli otomobiller için yüzde 3 ile yüzde 15 arasındadır. Bunun yanı sıra, elektrikli otomobiller için uygulanacak Motorlu Taşıtlar Vergi (MTV) tutarının eşdeğer fiyat aralığındaki benzin veya motorin yakıtlı araçlara uygulanan MTV tutarının yüzde 25’i oranında uygulanmasına karar verilmiştir (ODD, 2018).

\section{ELEKTRIKLII ARAÇLARIN ISTIHHAM, ÇEVRE VE DIŞ TICARET DENGESİ ÜZERİNE ETKİLERİ}

Otomotiv endüstrisi, yarattı̆̆ 1 istihdam, çevre ve diş ticaret üzerindeki etkileri ile gelişmiş ve gelişmekte olan ülkelerde ekonominin temel taşlarından biri olarak yer almaktadır. Türkiye'de ve dünyada elektrikli araçların gelişimi ile ilgili bilgilerin yer aldığı birinci bölümden sonra ikinci bölümde, elektrikli araçların yaygınlaşmasının ekonomide oluşturabileceği etkiler istihdam, çevre ve dış ticaret dengesi başlıkları altında yer 
almaktadir.

\section{1 İstihdam Üzerine Etkileri}

İçten yanmalı motorlu bir otomobilde otuz binden fazla parça vardır (Toyota, 2017). Bu otomobillerde bakım gerektiren ve arızaya yol açan kısımlar; motor, motor soğutma sistemi, motor ateşleme sistemi ve sık paslanıp değişim gerektiren egzoz boruları, susturucular gibi kısımlarıdır. Eşdeğer güçteki elektrikli bir otomobilde ise parça sayısı içten yanmalı motorun ortadan kalması ile yaklaşık olarak bu değerin yarısına düşmektedir. Dolayısıyla, elektrikli araçların bakım ve onarım maliyetleri de önemli ölçüde düşmektedir (Ünlü vd. 2003: 20-21).

Elektrikli araçların bakım ve onarım maliyetlerinin fosil yakıtlı araçlara göre düşük olması tüketiciler açısından toplam araç maliyetinin azalması yönünde bir etkiye sebep olmaktadır. Elektrikli otomobiller ile içten yanmalı motorlu otomobillerin bakım ve servis maliyetleri karşılaştırıldığında, on yıllık dönem için toplam bakım ve servis maliyetinin elektrikli otomobil için 5.500 TL iken bu değerin benzin motorlu bir otomobil için 15.000 TL, dizel motorlu otomobil için ise 16.500 TL olduğu ortaya çıkmaktadır (Renault yetkili servislerinden derlenen bilgiler ile hazırlanmıştır).

Otomobil kullanıcıları için avantaj yaratan bu durum otomotiv endüstrisinde satış sonrası ve yedek parça hizmeti veren firmalar açısından önemli bir dönüşümü beraberinde getirmektedir. Elektrikli araçların yaygınlaşması sonucunda, elektrikli araç paylaşım sistemleri, elektrikli araç dönüşüm istasyonları, yazılım ve pil/batarya teknolojisi, seyyar ve kablosuz şarj istasyonları, güneş panelli şarj istasyonları, araçların tavanlarındaki güneş paneli uygulamaları, çeşitli cep telefonu uygulamaları ve enerji depolama sistemleri gibi birçok yenilikçi teknoloji alanlarının ortaya çıkması ve dolayısıyla yeni istihdam olanaklarının oluşması beklenmektedir. Türkiye'de bu yeni istihdam alanlarının gelişmesi, pazarlanması, satış ve servis hizmeti sunulması ve üretilmesi sonucunda otomotiv endüstrisinde bir milyon kişiye ulaşabilecek yeni iş gücü alanının açılabileceği tahmin edilmektedir (Bayram, 2017).

Sonuç olarak, içten yanmalı motor ve buna bağlı donanımların yerini, yeni nesil elektrikli araçlarda batarya sistemi ve elektrik makinesi almaktadır. Türkiye’de elektrikli araçların üretimi söz konusu olduğunda, tedarikçilerin inovasyona son derece açık olan batarya ve batarya alt sistemlerin Ar-Ge alanlarında doğrudan desteklenmesi gerekmektedir. Şayet tedarik zincirinde yer alan üreticiler gerekli inovasyonu gerçekleştiremez ise, günümüzde motor ve motor aksesuarlarındaki dışa bağımlılık, 2020'li yıllarda batarya ve elektrik makinesinin dışa bağımlılığına dönüşebilecektir (OTEP, 2010: 12).

\section{2 Çevre Üzerine Etkileri}

Uluslararası Enerji Ajansı’nın 2017 raporuna göre, taşımacılık tüm dünyada karbon dioksit emisyonlarının yüzde 23'ünden sorumludur ve bu emisyonun önemli bir bölümü 
de fosil yakıtlı otomobiller tarafından üretilmektedir (IEA, 2017: 44). Çevre kirliliğini artıran geleneksel fosil yakıtlı araçlar yerine araștırmaları süren alternatiflerden biri de elektrikli araçlardır. Elektrikli araç sistemleri, sessiz olmaları, emisyon avantajları ve yakıt tasarrufu sağlamaları gibi faydaları sayesinde belirtilen sorunlara çözüm getirebilecek unsurlar arasında yer almaktadır (Haktanır, 2012: 9).

Elektrikli araçların çevre üzerindeki karbondioksit $\left(\mathrm{CO}_{2}\right)$ emisyonu etkilerinin hesaplaması konusunda bu araçların kaynaktan tekerleğe kadar olan durumunu göz önünde bulundurmak gereklidir. Emisyon faktörü, elektrik üretiminin hangi kaynaklardan yapıldığgna göre ülkeden ülkeye değişiklik göstermektedir (OTEP, 2010: 9). Mevcut enerji üretim olanakları ve tüm kullanım ömürleri dikkate alındığında elektrikli araçların fosil yakıt kullanan araçlara göre genel olarak yüzde 35 daha düşük karbondioksit emisyonuna sahip oldukları yani çok daha çevre dostu oldukları belirtilmektedir. Gelecekte elektrik üretiminde yenilenebilir enerji kaynakların payının artması durumunda bu faydaların daha da artacağı eklenmektedir (CE Delft, 2018).

Yüksek enerji verimleri ve elektrik üretiminde yenilenebilir enerji kaynaklarının kullanılması sayesinde elektrikli araçların emisyonlarının gelecekte daha da azalacağı tahmin edilmektedir. Elektrik üretimi mevcut karbondioksit seviyelerinde dahi olsa, 2030'da küresel ölçekte elektrikli araçların kullanımından ortaya çıkan karbondioksit emisyonunun eşdeğer miktardaki içten yanmalı motorlu araçlarınkine göre daha düşük olması beklenmektedir. Bu konuda yapılan hesaplamalara göre, mevcut tüm elektrikli araçların içten yanmalı motorlu olması durumunda, bu araçlar 2030'a dek 418 MtCO2 karbondioksit emisyonuna sebep olmaktadırlar. Oysa bu araçlar eşdeğer güçteki elektrikli motorları ile sadece 297 MtCO2'lik karbondioksit emisyonuna sahiptirler. Bu, elektrik kaynaklarında değişiklik olmaksızın $121 \mathrm{MtCO}$ 'lik bir emisyon avantajı anlamına gelmektedir. Elektrik kaynaklarının sürdürülebilir kaynaklardan temini dikkate alındığında ise, elektrikli araçların emisyonu ek olarak $56 \mathrm{MtCO} 2$ daha azalmaktadır (Global EV Outlook, 2018: 94).

Yakıt tasarrufu elektrikli araçların sunduğu diğer bir avantajdır. Yılda yaklaşık yirmi bin kilometre yol kat eden bir benzinli otomobilin yakıt gideri yaklaşık 10.016 TL, eşdeğer güçteki elektrikli otomobilin yakıt gideri ise aynı mesafe için 672 TL olarak ortaya çıkmaktadır (Benzin 6,26 TL/litre, elektrik ise gece tarifesi ile 28 kuruş/kilovatsaat olarak tarafımızdan hesaplanmıştır).

\subsection{Dış Ticaret Dengesi Üzerine Etkileri}

Türkiye’nin enerji (petrol ve doğal gaz) konusundaki dışa bağımlılık oranı yüzde 75 seviyelerindedir ve enerjisinin sadece yüzde 25’ini yurt içi kaynaklardan temin edebilmektedir (IEA Türkiye Raporu, 2016: 22). Buna bağlı olarak, Türkiye'nin cari işlemler açığı içinde enerjinin payı yüzde 70'tir ve bunun yaklaşık olarak yüzde 20'si karayolu ulaşımından kaynaklanmaktadır (Ataman, 2012: 106). Kaynağı yurt içinden temin edilen yenilenebilir enerjili ulaşım araçlarının üretilmesi ve kullanılması, Türkiye 
açısından bu nedenle cari açık ve büyüme için temel bir öneme sahiptir.

Otomotiv endüstrisi, Türkiye'nin ihracatında en önemli paya sahip sektörlerin başında gelmektedir. Endüstrinin ihracat1, 2017 yılında bir önceki yıla göre yüzde 19,5 artış göstererek toplam ihracat içinde 2005 yılından beri sahip olduğu liderliğini yüzde 18,2 pay ile korumuştur. Bunun yanı sıra, dış ticaret açığımızın 76,8 milyar seviyesine yükseldiği 2017 yılında otomotiv dış ticaret fazlası (GTIP 87 kapsamında belirlenen otomotiv dış ticaret verilerine göre) yüzde 232 oranında artarak 6,5 milyar dolar seviyesine yükselmiştir (OSD, 2018: 2).

Türkiye otomobil ihracatının önemli bir bölümünü Avrupa Birliği ülkelerine yapmaktadır. 2017 Kasım ayı sonu itibariyle, ülkemizin otomotiv endüstrisi ihracatının yüzde 77'den fazlası Avrupa Birliği ülkelerine yapılmıştır (KPMG, 2018: 11). Birlik, "Avrupa Birliği Stratejisi” çerçevesinde kaynak verimliliğini ve iklim değişikliğini dikkate alan ulaşım, çevre ve enerji politikalarını uygulamaktadır. Düşük karbon emisyonuna sahip ulaşım olanaklarının üretilmesi ve kullanılması da bu politikaların temel unsurlarından bir tanesidir. Avrupa Birliği, 2050 yılına kadar, karbon emisyonlarını 1990 seviyelerine yüzde 80-95 seviyesinde azaltmayı hedeflemektedir. Çevre dostu ulaşım sistemleriyle ilgili olarak elektrikle çalışan araçlar, yakıt hücreleri, biyoyakıtlar, doğalgaz ve güneş enerjisi gibi alternatif teknolojilerinin kullanılabilirliği gündemde olan konulardır (Haktanır, 2012: 9). $\mathrm{Bu}$ açıdan, sürdürülebilir enerji kaynağı kullanan ve elektrikli araçların üretiminde söz sahibi olmak, Türkiye’nin en önemli ihracat pazarını oluşturan Avrupa Birliği ülkelerine yönelik ticaret konusunda rekabet gücümüzü korumak ve hatta artırmak açısından önem taşımaktadır.

\section{LITERATÜR}

Otomotiv endüstrisindeki yeni stratejiler ve ürünler geçmişten beri pek çok araştırmacının ilgisini çekmiştir. Dicken, otomobil üreticilerinin iki önemli zorlukla karşılaştıklarını iddia etmiştir. Bu zorluklardan ilki etkin üretim süreçlerine yönelim iken diğeri emisyonlarla ilgili çevresel regülasyonların baskılarını karşılayacak ve tüketicilerin satın almaya hazırlandıkları araçlarda kullanılan yakıt miktarını azaltacak tipte farklı araç türlerinin üretilmesi şeklindedir. Yazara göre elektrikli, hibrit ve yakıt hücreli araçlardan oluşan yeni trendler de bu gelişmeler sonucunda ortaya çıkmıştır. Dicken, hibrit araçların önemli ilerleme kaydettiğini belirtirken elektrikli araçların gelişimi için elektronik ve otomotiv firmalarının güvenilir ve uzun ömürlü bataryaların Ar-Ge'si konusunda yoğunlaştıklarının altını çizmiştir (Dicken, 2015: 486).

Sperling, gelecekte araçların daha fazla elektrikli, otonom olacağını ve araç paylaşım sistemlerinin artacağını açıklarken elektrikli araçların yaygınlaşmasının güçlü politikalarla yavaş yavaş gelişeceğini belirtmiştir (Sperling, 2018: 21).

Hibrit ve elektrikli araçların ekonomik etkileri ve karşılaştırmaları ile ilgili sınırlı da olsa bazı çalışmalar yer almaktadır. Bu çalışmalarda genel olarak, hibrit ve tümü elektrikli 
araçların sağladığı katkıların ve genel anlamda içten yanmalı motorlu araçlara göre üstünlüklerinin elektriğin üretim kaynağına bağlı olarak değiştiği savunulmaktadır.

Elektriğin, yenilenebilir kaynaklardan sağlanması durumunda tümü elektrikli araçların, doğalgazdan üretilmesi durumunda ise hibrit araçların diğer otomobil türlerine göre daha avantajlı olduğu sonucuna varılmıștır (Granovskii vd, 2006).

Amerika Birleşik Devletleri’nin Kaliforniya eyaletinde çoğunluğu henüz elektrikli araç tecrübesi yaşamamış ve yeni araç satın almayı planlayan 508 tüketiciye 2011 yılında yapılan bir araştırmaya göre, en fazla tercih edilen araç türü elektrik ve içten yanmalı motorun bir arada kullanıldığ şarj edilebilir hibrit otomobiller olurken tümü elektrikli araçlar en az tercih edilen otomobil türü olmuştur. Tüketiciler, bu tercihlerini elektrikli araçların satın alma maliyetlerinin yüksek olması, elektrikli araç teknolojisinin yeterince güven kazanmamış olması, menzilin ve şarj istasyonlarının yetersiz olması şeklinde açıklamışlardır (Axsen ve Kurani, 2013).

Japonya'da yeni nesil araçların ulusal ve bölgesel açıdan yapacakları ekonomik etkileri girdi-çıktı modelleri yoluyla inceleyen çalışmada, otomobil endüstrisinde hibrit ve elektrikli araçlara geçişin sadece otomotiv endüstrisini değil ilgili diğer endüstri yapılarını da etkileyeceği sonucuna varılmıştır. Ayrıca, yeni teknolojilerden en fazla otomotiv endüstrisinin en yoğun olduğu bölgelerin etkileneceği açıklanmıştır (Shibusawa ve Miyata, 2017).

Tümü elektrikli, yakıt hücreli ve şarj edilebilir elektrikli araçları satın alma ve kullanım maliyetleri üzerinden karşılaştıran diğer bir çalışmaya göre, konvansiyonel içten yanmalı motorlu araçlarla karşılaştırıldığında, elektrikli araçların yüksek satın alma maliyetine, düşük yakıt giderlerine, düşük dişsal maliyete, muhtemelen yüksek sigorta maliyetine ve muhtemelen düşük bakım, onarım maliyetine sahip oldukları belirtilmektedir (Delucchi ve Lipman, 2010).

\section{ARAŞTIRMANIN YÖNTEMI}

Elektrikli araçların Türkiye'deki satışı 2012 yılında başladığından henüz oldukça yenidir ve dünya ülkeleri ile kıyaslandığında çok düşük seviyededir. Ülkemizde otomotiv endüstrisinin Türkiye ekonomisine katkıları konusunda birçok araştırma olmasına karşın gelecekte önemli bir yer tutacağı öngörülen çevre dostu ve elektrikli araçların etkileri ile ilgili sınırlı sayıda akademik çalışma bulunmaktadır. Bu çalışmaların çoğunluğu da fen bilimleri alanındadır. Öte yandan, otomotiv endüstrisi 2005 yılından beri Türkiye’nin ihracatında ilk sırada yer almaktadır ve bu endüstrideki teknolojik gelişmelerin ekonomik ve sosyal etkileri de ülkemiz açısından çok önem taşımaktadır.

Bu çalışmanın amacı, elektrikli araçların pazar payındaki artışların otomotiv endüstrisi istihdamı, çevre ve dış ticaret dengesi üzerindeki muhtemel etkilerini ortaya koyarak disiplinler arası araştırmalara katkıda bulunmaktır. Bu bağlamda, katılımcılara elektrikli 
araçların dünyadaki ve Türkiyedeki geleceğini nasıl gördükleri, bu araçların Türkiye ekonomisine katkıları ve Türkiye’de başarılı olmaları için gerekli unsurların belirlenmesine yönelik nitel araştırma tekniği kullanılarak yarı yapılandırılmış açık uçlu derinlemesine mülakat soruları hazırlanmıştır (Alshenqeeti, 2014: 40). Yarı yapılandırılmış açık uçlu soruların belirlenmesinde ise, konuya ilişkin araştırmalar, yayınlar ve hali hazırda otomotiv endüstrisinde çalışan beş yöneticinin görüşlerinden yararlanılmış ve benzerlik gösteren ortak ifadelerden dört soru hazırlanmıştır. Böylece araştırma konusuna yönelik var olan sınırlı bilgilere katkı sağlamak hedeflenmiştir.

Otomotiv endüstrisinde kolayda örnekleme yoluyla bilgi edinilebilecek yöneticilerle irtibata geçilmiş, Temmuz 2017-Mart 2018 döneminde görüşmeler gerçekleştirilmiştir. Yoğun iş programları çerçevesinde mülakat için zaman ayıran 5 katılımcı ile çalışmalar yürütülmüş, ziyaretlerde her iki araştırmacı da yer almıştır. Katılımcıların elektrikli araçlar konusunda faaliyet gösteren kuruluşlarda çalışıyor olması ve/veya bu alanda yayın yapmış olması dikkate alınmıştır. Katılımcılardan ilki, Türkiye'de üretilen ilk elektrikli araç olan Fluence ZE ve Mayıs 2018 itibariyle satışı süren araçlardan biri olan Renault Zoe elektrikli araçlarının satış ve satış sonrası hizmetlerini veren Renault MAİS firmasının Genel Müdürü-CEO’su Berk Çağdaş'tır. Renault ile Dacia otomotiv markalarının Türkiye Genel Distribütörü MAİS Motorlu Araçlar İmal ve Satış A.Ş. 10 Ocak 1968 tarihinde OYAK Grup şirketi olarak kurulmuştur ve ilk Renault marka otomobili Türkiye'de 1971 tarihinde satışa sunmuştur (Renault, 2017).

Katılımcılardan ikincisi, Türkiye’de Mart 2018 itibariyle satışı devam eden BMW İ3 elektrikli ve İ8 hibrit araçlarının ithalatından ve dağıtımından sorumlu olan Borusan Otomotiv BMW Ürün ve Fiyatlandırma Yöneticisi Murat Akcan'dır. Üçüncü katılımcı, Jaguar I-PACE tümü elektrikli aracının ithalatını ve satışını gerçekleştiren Jaguar ve Land Rover Elektrikli Otomobiller Müdürü Mustafa Güven'dir. Dördüncü katılımcı, ulusal kanallardan birinde otomotiv programları hazırlayıp sunan gazeteci ve eski otomotiv sektörü yöneticisi Saffet Üçüncü ve son katılımcı, sivil toplum kuruluşu Türkiye Elektrikli ve Hibrit Araçlar Platformu TEHAD'ın yayın yönetmeni ve yazarı Berkan Bayram'dır. Araştırmanın güvenilirliği çerçevesinde, mülakatlarda paylaşılan bilgilerin analizinde katılımcıların özgün yanıtlarına sadık kalınarak betimleyici bir yaklaşım ile gerekli görülen durumlarda birebir alıntılara yer verilmiştir.

\section{ARAŞTIRMANIN BULGULARI}

Araştırma sürecinde, beş katılımcı ile yüz yüze mülakatlar yapılmış ve bu doğrultuda veriler düzenlenmiştir. Katılımcılara, ilk olarak, araştırmanın amacı ve yöntemi ile ilgili bilgilendirme yapılmıştır. Katılımcılardan araştırma kapsamında isimlerinin, unvanlarının ve görüşlerinin açıklanması ile ilgili izinlerinin alınmasının ardından, dört ana soru aktarılmıştır. İlk soru; "Sizce gelecekte İçten Yanmalı Motorlu, dizel motorlu, elektrikli, doğal gaz, hidrojen ve yakıt hücreli araçların rolü ne olacak?” sorusudur. İkinci soru; "Elektrikli araçların dünyadaki ve Türkiyedeki geleceğini nasıl görüyorsunuz?" sorusu çerçevesinde başlıklandırılan kısımdır. Üçüncü soru ise; "Elektrikli araçların 
Türkiye ekonomisine katkıları (cari açık, istihdam, büyüme, çevre) sizce neler olabilir?” sorusudur. Dördüncü ve son soru ise "Elektrikli otomobillerin Türkiye'de başarılı olması için gerekli unsurlar sizce nelerdir?” sorusudur. Katılımcıların verdikleri tüm yanıtlar ve yorumlar, yanıtların yoğunluğunu ve yönünü belirlemek için sistematik bir yaklaşım olan içerik analizi tekniği kullanılarak harmanlanmış ve analiz edilmiştir (Erdoğmuş ve Çalışkan, 2011: 308-316).

\section{1 İçten Yanmalı Motorlu, Dizel Motorlu, Elektrikli, Doğal Gaz, Hidrojen ve Yakıt hücreli araçların Gelecekteki Rolleri ile İlgili Yönlendirilen Soruya Verilen Yanıtların Çözümlenmesi}

Mülakatın ilk sorusu; "Sizce gelecekte İçten Yanmalı Motorlu, dizel motorlu, elektrikli, doğal gaz, hidrojen ve yakıt hücreli araçların rolü ne olacak?” sorusudur. Katılımcılardan bu soruya alınan yanıtlar çerçevesinde, ortak görüş, Avrupa'da dizel motorlu araçların yasaklanması nedeniyle, gelecekte İçten Yanmalı Motorlu araçların pazar payının önemli ölçüde azalacağı ve buna karşılık elektrikli araçların pazar payının giderek artacağı görüşü etrafında toplanmaktadır.

\subsection{Elektrikli Araçların Dünyadaki ve Türkiye’deki Geleceği ile İlgili Yönlendirilen Soruya Verilen Yanıtların Çözümlenmesi}

Mülakatın ikinci sorusu, tümü elektrikli araçların dünyadaki ve Türkiye’deki geleceği ile ilgili olmuştur. Bu çerçevede, katılımcılara; "Elektrikli araçların dünyadaki ve Türkiye’deki geleceğini nasıl görüyorsunuz?" sorusu yöneltilmiştir. Katılımcıların bu soruya verdiği ortak görüş, elektrikli araçların Amerika Birleşik Devletleri ve Norveç başta olmak üzere İ́skandinav ülkelerinde daha yakın gelecekte yaygınlaşacağı, Türkiye'de ise daha uzun zaman alacağı yönündedir. Öte yandan, üretici firmaların çalışmalarına ve devlet teşviklerine bağlı olarak bu sürecin hızlanabileceğini de belirtmiştirler. Katılımcılardan bir tanesi, bu geçişte başlangıçta hibrit olmak üzere tüm yenilenebilir enerjili motorların pazar paylarının artacağını belirtmiştir.

\subsection{Elektrikli Araçların Türkiye Ekonomisine Katkıları ile İlgili Yönlendirilen Soruya Verilen Yanıtların Çözümlenmesi}

Mülakat sırasında katılımcılara sorulan üçüncü soru: "Elektrikli araçların Türkiye ekonomisine katkıları (cari açık, istihdam, büyüme, çevre) sizce neler olabilir?” olmuştur. Katılımcıların tamamı, İçten Yanmalı motor teknolojisinden elektrikli araç teknolojisine geçişin ve bu araçların Türkiye'de üretilmesinin çevre başta olmak üzere ülkemizin ekonomisinde olumlu etkileri olacağını belirtmişlerdir. Bir katılımcı, elektrikli araçların üretimde katma değeri artırmaları açısından gayrisafi milli hâsılaya (GSMH) katkıda bulunacaklarını belirtirken diğer iki katılımcı bu araçların akaryakıt kullanımını ve dolayısıyla cari açığımızı azaltmaları açısından olacağının üzerinde durmuştur. Öte yandan iki katılımcının ortak görüşü, elektrikli araçların bakım ve onarım masraflarının düşük olması nedeniyle, otomobil yan sanayinde istihdam açısından özellikle kısa vadede 
bir takım azalmaların olabileceği yönündedir. İki katılımcı ise bu araçların en büyük katkılarının karbon emisyon azaltılması yoluyla çevre üzerinde olacağını belirtmişlerdir.

\title{
Tablo 2: Katılımcıların "Sizce gelecekte içten yanmalı motorlu, dizel motorlu, elektrikli, doğal gaz, hidrojen ve yakıt hücreli araçların rolü ne olacak?” sorusuna yönelik öne çıkan yorumları
}

\begin{abstract}
Verilen Cevaplardaki Ortak İfadeler
“2020’li yıllarda Kuzey Avrupa ülkelerinden başlayarak Avrupa'da dizel motorlu araçların yasaklanması ile bu ülkelerde çevre dostu araçlara geçiş üç-beş yıl içerisinde daha radikal bir şekilde yaşanacak. Diğer ülkelerde ve Türkiye’de bu geçiş 10-15 yılı alabilir."

"Yakın gelecekte içten yanmalı motorlu araçların zaman içinde hayatımızdan tamamen çıkması ve onların yerini elektrikli araçların alması beklenmektedir. Bunun üç temel nedeni bulunmaktadır. Bu nedenlerden ilki, elektrikli araçların verimlerinin yüksek olmasıdır. Elektrik motorlarının verimleri, yüzde 95 civarında iken içten yanmalı motorlu araçlarda bu verim yüzde 35-40'ları geçmemektedir. Verim kadar önemli ikinci neden ise, egzoz emisyonlarını oluşturan azot oksit, hidrokarbon, karbon monoksit ve karbon dioksit insan sağlığ1 ve çevre açısından çok önemli tehlikeler olușturmasıdır. En önemli üçüncü neden ise, otomotiv endüstrisindeki dijitalleșmedir. Elektrikli otomobiller dijital olarak, otonom sürüşe de çok uygun olduklarından öne çıkıyorlar. Son bir yılda katıldığım yurtdışı fuarlarında gördüğüm gibi elektrikli otomobillerin menzilleri iki kata yakın hatta daha fazla artırılmış durumda. Bu konuda birçok yatırım devam ediyor. Tesla’nın Panasonic ile Nevadada yapmakta olduğu pil fabrikası bu konudaki gelişmelere güzel bir örnektir."

"Batarya teknolojisindeki gelişmeler sayesinde maliyetlerin düşmesi ile 2011 yılında 800 dolar olan batarya maliyeti 2017'de 300-400 dolara kadar indi. 2011'de dünya çapında 45.000 adet olan elektrikli araç sayısı 2017'de tümü elektrikli ve hibrit araçlar dâhil 2 milyon adede erişmiştir. Yakıt hücreli elektrikli otomobillerin fiyatları halen pahalıdır, 2030'dan sonra uygun fiyata düşebileceği tahmin edilmektedir. 2030'dan sonra, 10 araçtan dördünün elektrikli, birinin hidrojen elektrikli, beşinin ise konvansiyonel içten yanmalı motorlu araç olacağı tahmin ediliyor."

"Avrupada birçok ülkede dizel motorlu otomobillerin şehir içine girişleri yasaklanmaya başladı. Ülkeler bunu yasakladıkça üreticilerin de bu tip otomobilleri üretmeyeceklerini düşünüyoruz. Sonrasında benzinli otomobillerin tedavülden kalkacağını, yakıt hücreli araçların değil ama tümü elektrikli araçların artarak gideceğini tahmin ediyoruz."

“Üreticilerin ne üretecekleriyle, ülkelere verdikleri kotalarla alakalı olarak 2025’e dek elektrikli araçlar yerini alacak. Örneğin, 4 sene önce $300 \mathrm{~km}$. menzil bir hayal iken şu anda artık çok sık konuşulur hale geldi. Pil teknolojisinin gelişimiyle ileride 800-900 km. menzilin ortaya çıkmasıyla, insanların elektrikli araçlarla ilgili en büyük önyargısı olan menzil önyargısının bitimiyle elektrikli araçların farklı modellerle çok daha yüksek rakamlara ulaşacağını düşünüyoruz. 2020 yılında lüks segmentte otomobil üreten tüm üreticilerde elektrikli otomobil modeli mutlaka olacak."

"Elektrik dışında yakıt kullanan araçların hiçbiri elektrikli araçlar kadar efektif değil. Mesela, hidrojenin her yerden sızma olasılığı var. Ayrıca, doğal gaza ve bu araçlara baktığımızda kullanıcının her halükarda dışa bağımlılığı devam ediyor. Siz elektrikli aracınızı evinizden bile şarj edebilirken hidrojen yakıtını sadece spesifik yerlerden temin edebilirsiniz. Bunun için yatırım yapılması gerekirken elektrikli araçları şehir içinde kullanırken evimizdeki elektrikten faydalanabiliyoruz. Bu nedenle, elektrikli araç dışındaki araçların gelecekte çok fazla yaşayacağını düşünmmüyoruz."
\end{abstract}


Tablo 3: Katılımcıların "Elektrikli araçların dünyadaki ve Türkiyedeki geleceğini nasıl görüyorsunuz?” sorusuna yönelik öne çıkan yorumları

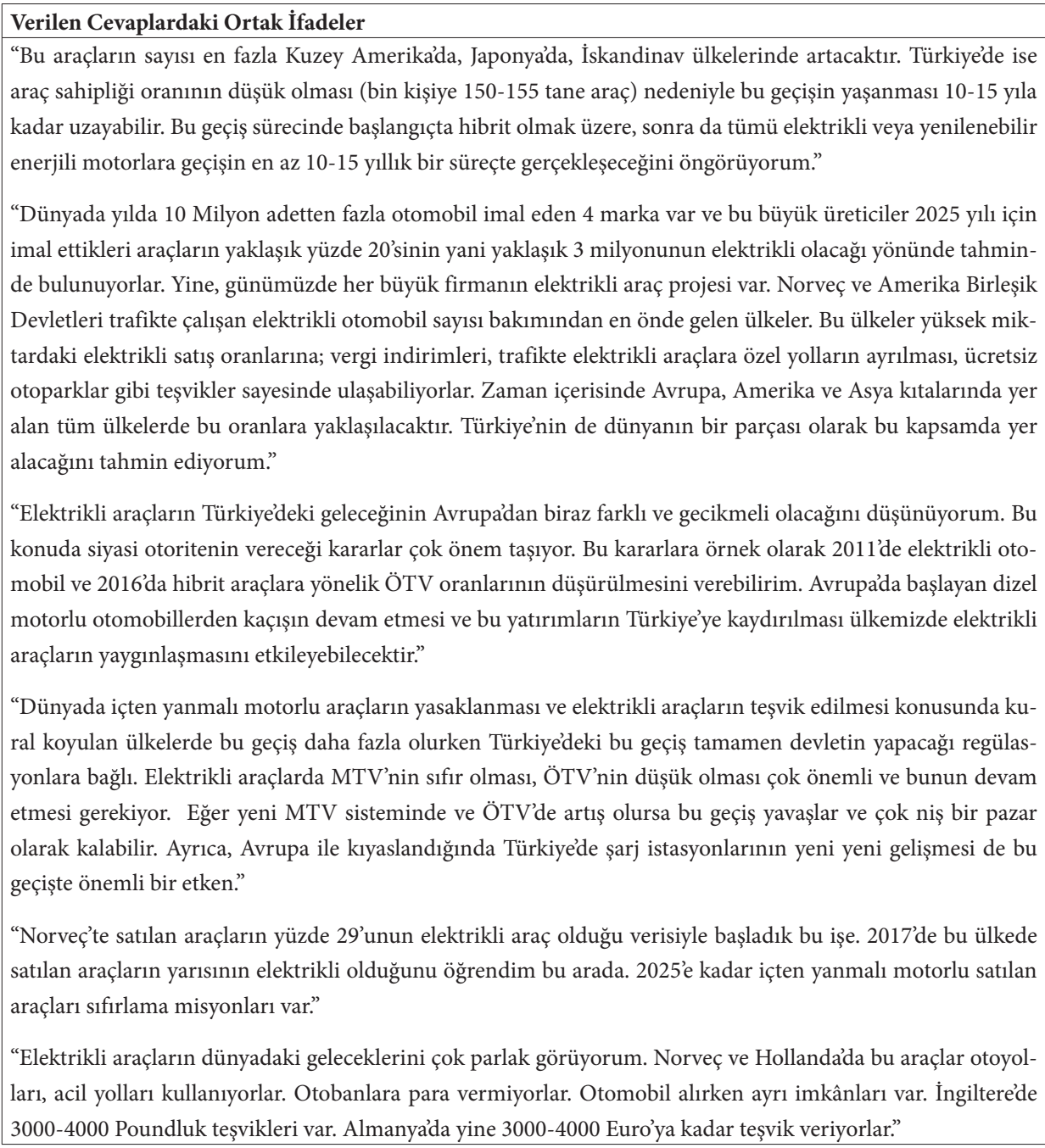


Tablo 4: Katılımcıların "Elektrikli araçların Türkiye ekonomisine katkıları (cari açık, istihdam, büyüme, çevre) sizce neler olabilir?” sorusuna yönelik öne çıan yorumları

\begin{abstract}
Verilen Cevaplardaki Ortak İfadeler
“Türkiye’de şu anda yaklaşık olarak 1,1 milyon civarında binek araç üretiliyor. Bu araçların 300 bin adedi orta vadede elektrikli üretilen araçlardan oluşsa bunun ekonomik katma değeri mevcut yapıya göre çok daha yüksek olacaktır. Bu katkı bizim analizlerimize göre, otomotivin GSMH üzerindeki katkısında en az yüzde 2- 3 civarında bir artış demektir. Orta vadede istihdama yönelik katkı ise ayrı bir konu, çünkü elektrikli araçlar daha teknoloji yoğun bir iştir. Normal içten yanmalı motorlu araç ve motor üretimi ve montajı ise daha emek yoğundur. Dolayısıyla bu anlamda, sanayinin daha etkin, verimliliği daha yüksek hale geliyor olması bir sonuçtur. Daha emek yoğun bir üretimden daha teknolojik ve katma değeri yüksek bir ürüne geçiştir."
\end{abstract}

"Elektrikli araçların yüzdesi arttıkça sıfır hata ile dünyadaki en kaliteli araçları imal eden bizim fabrikalarımızın üretimi de artacaktır. Bu doğrultuda, otomotiv fabrikalarımız ülkemizde cari açı̆̆ın kapatılması, ihracat ve istihdam bakımından önemli hizmetler yapıyorlar. Öte yandan, elektrikli otomobillerin yaygınlaşması ile otomobil servis hizmetlerini veren servislerin iş hacimlerinde azalmalar olacağını düşünüyorum. Yetkili servisler bu azalmaları telafi etmek için şarj istasyonlarının kurulması ve akümülatör gruplarındaki güç azalması ve arızalar konularında hizmetler vererek bu akümülatörlerin kesintisiz güç kaynağı olarak kullanılması konusunda çalışmalar yürütüyorlar."

"Devlet gelirlerinin önemli bir kısmı otomotiv sanayinden sağlanmaktadır. Elektrikli otomobillere geçilerek akaryakıt kullanımının azaltılması ile çevre kirliliğinin azaltılması başta olmak üzere cari açığımızda azalma olacağını tahmin ediyorum.”

"Elektrikli araçların, emisyon açısından evreye katkıları oldukça fazla. Ayrıca, petrolü dışarıdan aldığımız için bu yönde cari açığın azaltılmasına katkıda bulunabilirler. İstihdam olarak da, bu araçlar bataryanın üretilmesi veya istasyon kurulumu açısından faydalı olabilir. Ama ben çok fazla istihdam olanağı görmüyorum.”

"Elektrikli araçların en önemli katkısının çevre konusunda olduğunu düşünüyorum. Bu araçlar insan sağlığına zarar vermezken, içten yanmalı motorlu araçlar insan sağlığg için zararlı.”

\title{
5.4 Elektrikli Araçların Türkiye'de Başarılı Olması İçin Gerekli Unsurlar ile İlgili Yönlendirilen Soruya Verilen Yanıtların Çözümlenmesi
}

Mülakatın dördüncü ve son sorusu ise: "Elektrikli otomobillerin Türkiye'de başarılı olması için gerekli unsurlar sizce nelerdir?” olmuştur. Katılımcıların tümüne göre, elektrikli araçların Türkiyede başarılı olmaları için gerekli unsurların başında, kullanıcıların bu araçlar hakkındaki bilinç düzeylerinin yükseltilmesi ve güvenlerinin sağlanması gelmektedir. Bu konuda katılımcı cevaplarında ön plana çıkan ortak unsurlar; test sürüşleri, eğitim ve tanıtımlar, şarj sürelerinin kısalması, şarj istasyonlarının yaygınlaşması, tüketiciye sunulan finansal ve fiziksel kolaylıklar, üreticiye sunulan üretim ve ihracat teşvikleri olarak göze çarpmaktadır. 
Tablo 5: Katılımcıların "Elektrikli otomobillerin Türkiyede başarılı olması için gerekli unsurlar sizce nelerdir?” sorusuna yönelik öne çıkan yorumları

\begin{tabular}{|c|}
\hline Verilen Cevaplardaki Ortak İfadeler \\
\hline $\begin{array}{l}\text { "Türkiye'de elektrikli araçların kullanıcılara iyi anlatılması, tanıtılması ve onların güveninin sağlanması } \\
\text { gerekmektedir. Bu konuda, yaygın ve örgün basın yayın mecralarının kullanılması, insanlara ürünlerin test } \\
\text { ettirilmesi, teknolojik olarak üretilen ürünlerin arkasında durulması, elektrikli araçlardan alınan vergilerinin } \\
\text { sıfırlanması, elektrikli araç üretimi yapan firmalara KDV indirimlerinin, üretim ve ihracat teşviklerinin veril- } \\
\text { mesi, arazi verilmesi ve aynı zamanda istihdamda SGK desteklerinin verilmesi ön plana çıkmaktadır. Elektrikli } \\
\text { araçlar, yeni bir teknoloji olduğundan potansiyel müşterilerinin kalbine dokunması özellikle önem taşıyor." }\end{array}$ \\
\hline $\begin{array}{l}\text { "Belediyeler elektrikli otomobiller için ücretsiz veya indirimli otoparklar konusunda destek verebilir, bu araç- } \\
\text { lara özel, ekspres yollar tahsis edilebilir. Avrupada olduğu gibi şehir merkezlerine girişte fosil yakıtlı araçlardan } \\
\text { ek ücretler istenirken elektrikli otomobillerin ücretsiz olarak girmelerine izin verilebilir." }\end{array}$ \\
\hline $\begin{array}{l}\text { "Ülkemizde elektrikli araçların yaygınlaşması için modelin iyi seçilmesi, hızlı şarj istasyonlarının artırılması } \\
\text { ve çeşitli devlet desteklerinin artırılması gerekiyor. Elektrikli otomobil kullanımının yaygınlaşması kullanıcı } \\
\text { alışkanlıklarının değişimine bağlı olduğunu düşünüyorum. Bu araçlar topluma doğru anlatılmalı ve algı yöne- } \\
\text { timi iyi yapılmalı. Bu amaçla biz elektrikli araçlar hakkında düzenli olarak eğitim programları düzenliyoruz. } \\
\text { Tüketicilere finansal desteklerin verilmesinin yanı sıra şehirlerin belli alanlarında elektrikli araçlara öncelik } \\
\text { tanınabilir ve özel yolların tahsis edilebilir.” }\end{array}$ \\
\hline $\begin{array}{l}\text { “íçten yanmalı motorlu araçlara farklı vergilendirme, Avrupa'daki şehirlerin uyguladığı gibi kurallar konması, } \\
\text { içten yanmalı motorlu araçların emisyon vergisi ödemeleri gibi uygulamalar şarj istasyonlarıyla ilgili teşvik } \\
\text { verilmesi gerekiyor. Şarj istasyonları konusunda bizim firmamızda da çalışmalar yürütüyoruz. Müşteri açısın- } \\
\text { dan üç unsur var: Menzil, fiyat ve nerede şarj edeceği. Menzil bizim işimiz ama şarj istasyonu devletin ve bu } \\
\text { konuda çalışan firmaların yapabileceği bir konu.” }\end{array}$ \\
\hline $\begin{array}{l}\text { r firma olarak bizlerin bu } \\
\text { Diğer üretici firmaların da } \\
\text { serekiyor." }\end{array}$ \\
\hline
\end{tabular}

\section{SONUÇLAR VE ÖNERİLER}

20. yüzyılın başında elektrik motorlu araçların yerini alan içten yanmalı motorların 21. yüzyılın ortalarına doğru yerlerini hibrit ve elektrikli motorlara bırakma durumu, endüstrideki üçüncü önemli dönüşümün işaretlerini sergilemektedir. Küresel otomotiv üreticilerinden Nissan, çevreye duyarlılık ve sürdürülebilirlik stratejileri nedeniyle Avrupa genelinde dizel motorlu araçların satışlarını kademeli olarak durduracağını açıklamıştır. Volvo firması, 2019 yılından itibaren içten yanmalı motorlu araç üretimini durdurup, tamamen hibrit ve elektrikli araçlar üreteceğini belirtmiştir.

Elektrikli araçların pazar payı, özellikle Kuzey Avrupa ülkelerinden ve Amerika Birleşik Devletleri'nden başlayarak tüm dünyada artış gösterse de bu araçların içten yanmalı motorlu araçların pazar payına ulaşmasının zaman alacağı düşünülmektedir. 2017 itibariyle, 2 milyonu aşan elektrikli araç stokunun 2020 yılında 9 milyon ile 20 milyon ve 2025 yılında 40 milyon ile 70 milyon arasında olacağı tahmin edilmektedir (IEA, 2017: 6). 
Elektrikli araçların seri üretiminin ve satışlarının artmasında bazı faktörler ön plana çıkmaktadır. Bunlardan ilki, yenilikçi teknolojiler yoluyla batarya maliyetlerinin düşmesi, enerji yoğunluklarının artması sonucunda şarj edilme sürelerinin kısalmasıdır. Halen devam eden araştırma faaliyetlerindeki sürekli iyileştirmeler sayesinde elektrikli araçlar ile içten yanmalı motorlu araçlar arasındaki maliyet farkının giderek azaldığ 1 gözlenmektedir. Diğer faktör, elektrikli araçların üretilmesini ve kullanımını avantajlı hale getirecek eğitimlerin, finansal ve fiziksel desteklerin sunulmasıdır. Tüketicilere bu araçlarla ilgili doğru bilgilendirme ve tanıtım yapılması, araçların satış fiyatlarında vergi indirimi/muafiyeti verilmesi, üretici firmalara araştırma, geliştirme, üretim ve satış teşviklerinin verilmesi, arazi tahsisinin yapılması, istihdama yönelik teşviklerin verilmesi, kamu araçlarının bu araçlardan teşkil edilmesi, şarj istasyonlarının yaygınlaştırılması katılımcılarımızın da vurguladığı destekler arasında yer almaktadır.

Belediyelerin elektrikli bisikletlerin ve otobüslerin kullanımlarını teşvik etmesi de yine elektrikli sürüşü yaygınlaştırabilecek unsurlardan bir tanesidir. Bunun yanı sıra, Avrupa Birliği ve Japonyadda olduğu gibi benzinli araçların vergi oranlarının yüksek tutulması da fosil yakıtlı araçların sebep olduğu negatif dışsallıkları azaltacak ve elektrikli araçların yaygınlaşmasını destekleyebilecektir. Türkiye'de tümü elektriklere sunulan önemli vergi avantajına rağmen bu araçların pazar payının diğer ülkelere göre çok düşük kalması, bu araçlar konusunda yeterince toplum bilincinin oluşmadığını ve güveninin sağlanmadığını kanıtlamaktadır. Bu bağlamda, konuyla ilgili tüm paydaşların çabası önem taşımaktadır.

Türkiye, günümüzde Avrupa'nın hafif araç üretiminin yaklaşı olarak yüzde sekizini ve küresel otomotiv üretimin yüzde 1,7'sini gerçekleştirmektedir. Ülkemiz elektronik ve beyaz eşya sektörlerindeki başarısına benzer biçimde önemli bir bölgesel araç üretim merkezi kurarak, araç üretiminde uzun vadede bir artı̧̧ yaşayabilir. Bu çerçevede, elektrikli araçların üretiminin ve satışının artması, bölgesinde zaten önemli bir otomotiv üretim merkezi olan ülkemiz açısından yüksek teknolojili ürün üretimimizin artırılması, enerji kaynaklı dış ticaret açığımızın azaltılması ve sürdürülebilir bir ekonomiye sahip olabilmemiz açısından önemli bir fırsat olarak görünmektedir.

Zaman azlığı sebebiyle sadece beş katılımcı ile görüşebilmiş olmamız araştırmamızın kısıtını oluşturmaktadır. Mülakatlar sürecinde, katılımcıların samimiyet ve gerçek fikirlerini yansıtacak biçimde sorulara yanıt verdikleri varsayılmıştır. Araştırmanın genelleştirilmesi açısından, katılımcı sayısının artırılarak ve Türkiye’nin yanı sıra diğer ülkelerden katılımcılara da yer vermek gelecekte bu alanda araştırma yapacaklara yeni bir yaklaşım sunabilir. 


\section{KAYNAKÇA}

Alshenqeeti, H. (2014). Interviewing as a Data Collection Method: A Critical Review, Vol. 3, No. 1 .

Ataman, O. (2012), “Elektrikli Araçlar Konusuna Genel Bir Bakış”, Yenilikçilik ve Çevre Açısından Ankara'da Elektrikli Araçlar Tartışma Toplantısı, Türkiye Çevre Vakfı Yayını, No: 188.

Axsen, J. ve Kurani, K.S. (2013). Hybrid, plug-in hybrid, or electric-What do car buyers want? Energy Policy, 61: 532-543.

Bayram, B. (2017, 12 Aralık). Elektrikli Otomobil Bir Milyon Kişiye İstihdam Sağlayacak. Hürriyet Gazetesi, Erişim Adresi: http://www.hurriyet.com.tr/teknoloji/elektrikliotomobil-bir-milyon-kisiye-istihdam-saglayacak-40675653.

Bedir, A. (2002). Türkiye’de Otomotiv Sanayi Gelişme Perspektifi, DPT Yayın No: 2660.

British Petrolium (BP), Erişim Tarihi: 23.07.2017, http://www.bp.com/en/global/ corporate/energy-economics/energy-outlook/electric-cars-and-oil-demand.html.

British Petrolium (BP), Erişim Tarihi: 23.07.2017, http://www.bp.com/en/global/ corporate/technology/technology-now/unconventional-gas.html.

Ce Delft, Erişim Tarihi : 29.07.2018, https://www.cedelft.eu/en/publications/1561/ indirect-and-direct-co2-emissions-of-electric-cars

Delucchi, M. ve Lipman, T. (2010). "Electric and Hybrid Vehicles” içinde, Pistoia, G., Elsevier.

Dicken P., 2015, Global Shift Mapping the Changing Contours of the World Economy, 7th Edition, New York, London: The Guilford Press.

Erdoğmuş, I., Çalışkan M. (2011). Online Group Buying: What Is There For the Consumers? 7th International Strategic Management Conference Procedia Social and Behavioural Sciences 24 .

Freeman, C. ve Soete, L. (2004). Yenilik İktisadı, Tübitak Yayınları Akademik Dizi: 25. Basım, Ankara.

Global EV Outlook.(2013). Electric Vehicles Initiative, Understanding the Electric Vehicle Landscape to 2020. International Energy Agency.

Global EV Outlook. (2018). International Energy Agency.

Granovskii, M., Dincer, I., ve Rosen, M.A. (2006). Economic and environmental comparison of conventional, hybrid, electric and hydrogen fuel cell vehicles, Journal of Power Sources, 159.

Haktanır K. (2012). "Elektrikli Araçlar Konusuna Genel Bir Bakış”, Yenilikçilik ve Çevre Açısından Ankarada Elektrikli Araçlar Tartışma Toplantısı, Türkiye Çevre Vakfı Yayını, No: 188. 
International Energy Agency, (2017), Tracking Clean Energy Progress 2017, Energy Technology Perspectives 2017 Excerpt Informing Energy Sector Transformations.

Jaguar Türkiye, Erişim Tarihi: 05.05.2018, http://www.jaguar-turkiye.com/jaguar-range/ipace/index.html?utm_source=DirectLink\&utm_medium=popup_ipace_kmi\&utm_ campaign=JaguarIPACE_January2018\&form=beni_haberdar_et\&email=

KPMG, (2018), Otomotiv Sektörel Bakış Dergisi.

Lepetun, J. (2011). Flowing with the Current, The Political Economy of Electric Car Industry, USA. Lambert Academic Publishing.

McGrath, M. 2.06.2017 tarihli BBC haberi, http://www.bbc.com/turkce/haberlerdunya-40128876.

Otomotiv Distribütörleri Derneği, Erişim Tarihi: 29.07.2018, http://www.odd.org.tr/ folders/2837/categorial1docs/2182/BasinBulteni\%203\%20Temmuz\%202018.pdf.

Otomotiv Distribütörleri Derneği, Erişim Tarihi: 30.07.2018, http:// www.odd.org.tr/web_2837_ 1 / entitialfocus.aspx?primary $\mathrm{id}=2104 \&$ type $=31 \& \operatorname{target}=$ categorial $1 \&$ detail $=$ single\&sp_table $=\&$ sp_primary $=\&$ sp_ table_extra=\&openfrom $=$ sortial

Otomotiv Distribütörleri Derneği Dergi, (2018), Otomotiv ve Yeni Stratejiler, Sayı 76.

Otomotiv Sanayii Derneği, (2017) Otomotiv Sanayii Dış Ticaret Raporu.

Otomotiv Teknoloji Platformu, (2010). Elektrikli Araç Çalışma Grubu Raporu.

Özpeynirci, E., (2017, 17 Temmuz). Irak ve İran Çarpılacak, Hürriyet Gazetesi, s. 8.

Renault MAİS, Erişim Tarihi: 26.07.2017,https://www.renault.com.tr/renault-kesfet/ renault-turkiye/renault-mais.html.

Shibusawa, H., ve Miyata, Y. (2017). Evaluating the Economic Impacts of Hybrid and Electric Vehicles on Japan's Regional Economy: Input-Output Model Approach. Socioeconomic Environmental Policies and Evaluations in Regional Science.

Sperling, D. (2018), Three Revolutions Steering Automated, Shared, and Electric Vehicles to a Better Future, Island Press.

Türkiye Elektrikli ve Hibrit Araçlar Platformu, Erişim Tarihi: 25.07.2018, http://tehad. org/2018/07/06/elektrikli-ve-hibrid-otomobil-satis-rakamlari-aciklandi/

Tesla İnternet Sitesi, Erişim Tarihi: 24.07.2017, https://www.tesla.com/blog/tesla-andpanasonic-collaborate-develop-nextgeneration-battery-cell-technology.

The Guardian, Erişim Tarihi: 25.07.2018, https://www.theguardian.com/business/2017/ jul/05/volvo-cars-electric-hybrid-2019.

Toyota İnternet Sitesi, Erişim Tarihi: 26.07.2017, http://www.toyota.co.jp/en/kids/ $\mathrm{faq} / \mathrm{d} / 01 / 04 /$. 
TÜIK, http://www.tuik.gov.tr/PreHaberBultenleri.do?id=24598. Erişim Tarihi: 04.05.2018.

Ustabaş, A., (2013). Mikro ve Makro Etkileri Yönünden Elektrikli Otomobiller (Türkiye Ekonomisi Örneği) Doktora Tezi.

Ünlü, N.; Karahan, Ş.; Tür, O.; Uçarol, H.; Özsu, E.; Yazar, A.; Turhan, L.; Akgün, F.; Trrıs, M. (2003). Elektrikli Araçlar, Tübitak Marmara Araştırma Merkezi Enerji Sistemleri ve Çevre Araştırma Enstitüsü, Gebze, Kocaeli. 